\title{
Camel Milk-Clotting Using Plant Extracts as a Substitute to Commercial Rennet
}

\author{
Imen Fguiri $\mathbb{D}^{1},{ }^{1}$ Moufida Atigui, ${ }^{2}$ Amel Sboui, ${ }^{1}$ Arroum Samira, ${ }^{1}$ Chayma Marzougui, ${ }^{2}$ \\ Mohamed Dbara, ${ }^{1}$ Mohamed Hammadi, ${ }^{1}$ and Touhami Khorchani ${ }^{1}$ \\ ${ }^{1}$ Livestock and Wild Life Laboratory, Arid Land Institute (IRA), Medenine 4119, Tunisia \\ ${ }^{2}$ Higher School of Agriculture Mateur, University of Carthage, Mateur 7030, Tunisia \\ Correspondence should be addressed to Imen Fguiri; imen.fguiri@yahoo.com
}

Received 23 December 2020; Accepted 1 March 2021; Published 5 March 2021

Academic Editor: Murat Senturk

Copyright (C) 2021 Imen Fguiri et al. This is an open access article distributed under the Creative Commons Attribution License, which permits unrestricted use, distribution, and reproduction in any medium, provided the original work is properly cited.

\begin{abstract}
The transformation of camel milk into cheese is an operation considered very delicate because of several difficulties encountered in achieving coagulation. The present study aims to improve coagulation abilities of camel milk using enzyme extracts from pineapple, kiwi, and ginger. Our results concerning the characterization of the enzymatic extract showed an extraction yield that varies according to the type of extract (pineapple: $75.28 \% \pm 4.59$, kiwi: $63.97 \% \pm 5.22$, and ginger: $28.64 \% \pm 1.47$ ). The optimum coagulation conditions of the 3 types of extract were as follows: for pineapple: $\mathrm{pH}=5$ and temperature $=45^{\circ} \mathrm{C}$; for kiwifruit: $\mathrm{pH}=6.6$ and temperature $=40^{\circ} \mathrm{C}$; and for ginger: $\mathrm{pH}=6.6$ and temperature $=45^{\circ} \mathrm{C}$. A fresh cheese was made from camel milk with a particular nutritional quality and consistency. The kiwi proteases displayed chymosin-like properties and thus hold the best potential for use as a milk coagulant in cheese production.
\end{abstract}

\section{Introduction}

Camels (Camelus dromedarius) are of particular interest in arid and desert regions. Their unique adaptability makes this species ideal for exploitation facing the challenges of global warming and perfect allies for food security under changing climate. Camel milk is mainly consumed raw just after milking or fermented but rarely processed into cheese [1] due to a low amount of $\kappa$-casein [2]. Hence, several studies focused on the functional and coagulation properties of the camel milk's proteins [3-6]. In spite of the above difficulties, satisfactory cheese can be made when cheese-making procedures are adapted to camel milk's particular characteristics [7]. A lot of work was dedicated to improve coagulum formation process using various proteolytic enzymes obtained from animal, plant, and microbial sources.

In general, bovine chymosin is the most used enzyme in a cheese-making procedure. However, the availability of calf rennet has become limited due to the worldwide increase in cheese manufacture, coupled with the reduction in the slaughter of calves due to their low meat production, and has led to search for alternative milk-clotting enzymes, as appropriate rennet substitutes [8-10]. Proteases from plant sources offer a high potential as nonanimal rennet alternative in production of cheese, food (e.g., production of novel dairy products, meat tenderizers, and protein hydrolyzate production), and medicine (e.g., digestive and anti-inflammatory agents) [11, 12]. An increasing interest toward milk-clotting agents obtained from plants in cheese industry has been noticed because of their easy availability and simple purification processes $[9,13]$. Furthermore, the use of plant proteases in cheese manufacturing promotes the greater acceptability by the vegetarians, some religious groups, and exigency of banning genetically engineered food [14]. For years, plant extracts have been used as milk coagulants in traditional cheeses which are mainly produced in Mediterranean countries, West Africa, and Asia [15]. Indeed, dried cardoon flowers of Cynara cardunculus L. and Cynara humilis L. have been used for centuries in the Iberian Peninsula to prepare certain varieties of cheese with a creamy soft-texture and exquisite flavor. The aspartic proteases cardosins and cyprosins (also 
called cynarases) are the main milk-clotting proteases present in the cardoon extracts [16]. In addition, the juice from the leaves of sodom apple (Calotropis procera) has been used in the African regions of Nigeria and Benin for traditional cheese-making [17], and in the south of China, the rhizome ginger juice is used to produce a ginger milk curd which is highly appreciated due to its tofu pudding-like, sweet-snack characteristics [18]. The common plant proteases papain and ficin (from papaya and fig, respectively) have a low milk-clotting activity/proteolytic activity (MCA/ $\mathrm{PA}$ ) ratio and have often been mentioned as the principal obstacle to their utilization in cheese-making [19]. Besides texture, the flavor of cheeses may also be affected by the type of plant extract used which leads to bitterness in the final product [14]. Use of fruit extracts such as kiwi (Actinidia L.), pineapple (Ananas comosus L. Mer), and ginger rhizome (Zingiber officinale Roscoe) extract resulted in less off-flavor notes, which are attributed to the production of short peptides that are responsible for bitterness in dairy products when ficin (fig or papaya protease) is used [18]. Moreover, high proteolytic activity has been recorded within the cysteine proteases actinidin (or kiwellin), bromelain (pineapple enzyme), and zingibain (ginger protease) that have potential applications in food industry $[18,20]$.

Hence, the objective of the present study was to evaluate the camel milk-clotting activities of ginger, pineapple, and kiwi extracts in terms of temperature dependence and their performance on yield and textural properties of curds during cheese-making, compared to commercial rennet.

\section{Materials and Methods}

2.1. Samples. Fresh kiwi (Actinidia deliciosa), pineapple (Ananas comosus L. Mer), and ginger rhizomes (Zingiber officinale) were obtained from a local market (Medenine, Tunisia). Camel chymosin FAR-M was obtained from CHYMAX $^{\circledR}$ M. 1000 International Milk-Clotting Units (IMCU) ml/l, Chr. Hansen A/S, Hørsholm, Denmark. Fresh camel milk was collected from female camels (Camelus dromedarius) belonging to the Arid Land Institute (IRA Medenine, Tunisia). Samples were brought to the laboratory in an isotherm container and were analyzed and processed upon arrival.

2.2. Preparation of Extracts. Extracts were prepared as described by Mazorra-Manzano et al. [21]. In brief, kiwi, pineapple, and ginger rhizomes were peeled and sliced. Then, water extracts were prepared by adding one equal part (w/v) of $20 \mathrm{mM}$ sodium phosphate buffer ( $\mathrm{pH}$ 7.2). Water extracts were homogenized and then centrifuged at $5000 \mathrm{~g}$ for $30 \mathrm{~min}$ at $4^{\circ} \mathrm{C}$ (Thermo Electron LED $\mathrm{GmbH} \mathrm{Am}$ Kalkberg, Germany) and filtered through a double cheesecloth to remove suspended particles. Fresh extracts were stored at $4^{\circ} \mathrm{C}$ and were either used the same day for protein and milk-clotting activity determination or frozen at $-20^{\circ} \mathrm{C}$ for further use.

$\mathrm{pH}$ and dry matter of enzymatic extract were determined using International standard methods [22]. The protein content was determined according to the Bradford method [23], using bovine serum albumin (BSA) as standard.

2.3. Optimization of $\mathrm{pH}$, Temperature, and $\mathrm{CaCl}_{2}$ Concentrations. Optimum $\mathrm{pH}$ and temperature were determined according to the method of Kunitz [24]. To determine the optimal $\mathrm{pH}$ for the enzyme activity, $1 \mathrm{ml}$ of plant extract was added to $10 \mathrm{ml}$ of camel milk at different $\mathrm{pH}$ values $(5,5.6,6.2,6.6,7.5$, and 8.5$)$ at $30^{\circ} \mathrm{C}$, and flocculation time (Tc) was measured. In order to determine the optimum temperature, the purified enzyme solution was incubated with casein solution at various temperatures ranging from 30 to $60^{\circ} \mathrm{C}$ for $10 \mathrm{~min}$ in a controlled temperature water bath and the flocculation time was noted. The optimal $\mathrm{CaCl}_{2}$ concentration was prepared by dissolving $12 \mathrm{~g}$ of skimmed milk powder in $100 \mathrm{ml}$ of $\mathrm{CaCl}_{2}$ solution with a calcium ion concentration range of 0.01 to $0.09 \mathrm{M}$ and added in tubes containing $10 \mathrm{ml}$ of milk at $\mathrm{pH}=6.6$ and at $T=30^{\circ} \mathrm{C}$, and the flocculation time was then determined.

2.4. Milk-Clotting Activity. The milk-clotting activity (MCA) of each extract was determined according to the Berridge method [25] modified by Collin et al. [26] with some modifications. One unit of enzymatic activity or rennet unit (RU) corresponds to the number of units of weight or volume of milk that can be coagulated with $1 \mathrm{ml}$ of coagulant preparation in 100 seconds and at optimal $\mathrm{pH}$ and temperature for each plant extract or commercial rennet. The time needed for curd formation was recorded (Tc). MCA was expressed as RU units and calculated as follows:

$$
\mathrm{RU}=\frac{\left(10^{*} V\right)}{\left(\mathrm{Tc}^{*} \mathrm{Q}\right)},
$$

where RU: unit of coagulating activity or rennet unit, $V$ : volume of substrate $(\mathrm{ml}), Q$ : volume of coagulant extract $(\mathrm{ml})$, and Tc: flocculation time (sec).

2.5. Proteolytic Activity. Proteolytic activity was determined by the method of Bergere and Lenoir [27] using BSA as a substrate. In brief, $1 \mathrm{ml}$ of $1 \%$ protein substrate solution (0.1 M phosphate buffer, $\mathrm{pH} 7.0$ ) was mixed with $1 \mathrm{ml}$ of coagulant and incubated for $60 \mathrm{~min}$ at $35^{\circ} \mathrm{C}$. After incubation, the reaction was stopped by the addition of $1 \mathrm{ml}$ of $12 \%$ $(\mathrm{w} / \mathrm{v})$ trichloroacetic acid. The mixture was vortexed vigorously. The absorbance of the clear filtrate was measured at $280 \mathrm{~nm}$. One unit of the enzymatic activity (U) was defined as the amount of protein that gave an increase of one unit in the absorbance at $280 \mathrm{~nm}$ under the described conditions.

2.6. Cheese-Making Process. Fresh camel milk was pasteurized at $65^{\circ} \mathrm{C}$ for 30 minutes and then cooled to $40^{\circ} \mathrm{C}$. The starter culture (Lactococcus lactis) isolated from artisanal fermented milk was then added to decrease $\mathrm{pH}$ at 5.5. After about one hour, the enzymatic preparation was then added at the rate of $10 \%$ of milk and mixed thoroughly. The mixture was incubated for 24 hours at $37^{\circ} \mathrm{C}$. After 
coagulation, the whey was drained to obtain a fresh cheese and kept at $4^{\circ} \mathrm{C}$ for further analysis.

2.7. Cheeses Characterization. The physicochemical characteristics were determined using International standard methods [22]. The protein content was determined according to the Bradford method [23], using BSA as standard. The moisture content $(\mathrm{Hm})$ was calculated according to the following formula:

$$
\mathrm{Hm}=100-\mathrm{DMC},
$$

where Hm: humidity (\%) and DMC: dry matter content.

As microbiological analysis, the total viable counts were determined on a plate count agar (Oxoid Ltd., Basingstoke, $\mathrm{UK})$ at $30^{\circ} \mathrm{C}$ for $72 \mathrm{~h}$; total coliforms on violet red bile agar (Oxoid) at $30^{\circ} \mathrm{C}$ for $24 \mathrm{~h}$; mesophilic and thermophilic lactobacilli on MRS agar (Oxoid) at $30^{\circ} \mathrm{C}$ and $45^{\circ} \mathrm{C}$ for $48 \mathrm{~h}$ under anaerobiosis, respectively; lactococci on M17 agar (Oxoid) at $30^{\circ} \mathrm{C}$ for $48 \mathrm{~h}$; and yeasts and molds on Worth agar (Oxoid) at $30^{\circ} \mathrm{C}$ for $72 \mathrm{~h}$. Results were expressed as log colony-forming units per $\mathrm{ml}$ of milk or gram of cheese.

The fat-soluble and water-soluble vitamins were determined by LC-MS chromatography according to AlbalaHurtado et al. [28].

Minerals in milk and cheese were quantified using Flame Atomic Absorption Spectrometer (ICE 3000 SERIES AA Spectrometer).

2.8. Texture Profile Analysis. Texture properties (TPS) of the cheese samples were determined by a Texture Analyzer Brookfield (model CT-3, MA, USA). Cheeses were carefully cut into pieces $(15 \times 15 \mathrm{~mm})$ with a cheese slicer and compressed to eliminate the air for 1 hour, and the values have been read directly. 2 parameters were set (penetration speed: $2 \mathrm{~m} / \mathrm{s}$; the distance of penetration: $10 \mathrm{~mm}$ ).

2.9. Sensory Analysis. Samples of cheese were subjected to sensory evaluation by 42 untrained panellists. Cheese samples were assessed for their taste, color, flavor, acidity, and texture. Panellists received a set of four samples per session, representing cheeses made with different plant extracts and the control made with chymosin. Each sample was evaluated in duplicate. The panellists were asked to drink plain water at the beginning of the sensory evaluation and between samples to try to make the palate conditions similar for each sample. Cheese traits are rated on the basis of $10 \mathrm{~cm}$ unstructured lines with 10 points scale $(0=$ lower intensity and 10 for higher intensity). Scores were the distances $(\mathrm{cm})$ from the left anchor point. At the end of sensory evaluation, panellists were asked to rank overall cheese acceptability.

2.10. Statistical Analysis. The experiments were conducted in triplicate, and data were presented as the mean \pm standard deviation. Data related to physicochemical characteristics, TPS, and sensory analysis were subjected to analysis of variance (ANOVA) using the SPSS 20. Duncan's multiple range tests were used to test differences between means with type of rennet as the main factor.

\section{Results and Discussion}

3.1. Characterization of Enzymatic Extract. The physicochemical characteristics of the enzymatic extracts obtained are shown in Table 1. A significant difference was observed in the $\mathrm{pH}$ value, dry matter, and proteins between the three types of extract. The highest $\mathrm{pH}$ was observed in ginger with a value of $5.24 \pm 0.06$, pineapple $3.58 \pm 0.01$, and kiwi $3.46 \pm 0.01$. The dry matter content was higher for ginger extract $(116.15 \pm 3.25 \mathrm{~g} / \mathrm{L})$ than kiwi and pineapple $(88.45 \pm 1.55 \mathrm{~g} / \mathrm{L}$ and $85.15 \pm 4.95 \mathrm{~g} / \mathrm{L}$, respectively). The kiwi and pineapple had significantly higher protein content $(80.58 \pm 7.42 \mathrm{~g} / \mathrm{L}$ and $74.08 \pm 1.25 \mathrm{~g} / \mathrm{L}$, respectively).

\subsection{Optimum Conditions of the Enzymatic Extract Clotting} Activity. As shown in Figure 1, the temperature for optimal clotting activity of different extracts studied in this assay was at $45^{\circ} \mathrm{C}$ for pineapple and ginger and at $40^{\circ} \mathrm{C}$ for kiwi. The effect of temperature proceeds mainly on the secondary phase of coagulation, which corresponds to the aggregation step. This is due to the importance of hydrophobic interactions in the aggregation of hydrolyzed micelles [29].

The optimal clotting activity was at $\mathrm{pH} 5$ for pineapple extract and 6.6 for kiwi and ginger extracts. Ramet [30] reported that all enzymes used in cheese manufacture are acidic proteases, and their activity is generally optimal at $\mathrm{pH}$ values close to 5.5. Few studies on milk-clotting substitutes for calf rennet applied to camel milk are available. Our findings differed from those reported by Hailu et al. [5] who found optimal clotting activity of ginger at a $\mathrm{pH}$ value of 5.0, a temperature of $65^{\circ} \mathrm{C}$, and crude extract concentration of $10 \%$ by volume to coagulate camel milk. Grozdanovic et al. [14] reported that kiwifruit extract prepared at $\mathrm{pH} 5.0$ showed patterns of coagulum and whey proteins comparable with those obtained by chymosin using bovine milk. Truc et al. [31] found that optimum temperature for bromelain, pineapple protease, amounts to $10^{\circ} \mathrm{C}-25^{\circ} \mathrm{C}$ in an acidic environment ( $\mathrm{pH} 4.6-5.2$ ), it refers to $40^{\circ} \mathrm{C}-60^{\circ} \mathrm{C}$ in a neutral one ( $\mathrm{pH} 6.8-7.1$ ), and only $80 \%$ of bromelain remains active at $70^{\circ} \mathrm{C}$ and $\mathrm{pH} 3.5-3.8 . \mathrm{CaCl}_{2}$ concentration has no significant effect on clotting activity. Similar results were mentioned by Castillo et al. [32], who considered that the main effect of $\mathrm{CaCl}_{2}$ is important on aggregation and firming. Thus, it is usually added as a texturing agent. Indeed, the presence of ionized calcium is essential for the achievement of the secondary phase of milk coagulation since $\mathrm{Ca}^{2+}$ ions neutralize negative casein micelle residues to form a firm curd in the second phase of the coagulation process [33]. 
TABle 1: Physicochemical characterization of the three enzymatic extracts.

\begin{tabular}{lccc}
\hline Extract & $\mathrm{pH}$ & Dry matter $(\mathrm{g} / \mathrm{L})$ & Proteins $(\mathrm{g} / \mathrm{L})$ \\
\hline Pineapple & $3.58 \pm 0.01^{\mathrm{b}}$ & $85.15^{\mathrm{b}} \pm 4.95$ & $74.08^{\mathrm{a}} \pm 1.25$ \\
Kiwi & $3.46 \pm 0.01^{\mathrm{c}}$ & $88.45^{\mathrm{b}} \pm 1.55$ & $80.58^{\mathrm{a}} \pm 7.42$ \\
Ginger & $5.24 \pm 0.06^{\mathrm{a}}$ & $116.15^{\mathrm{a}} \pm 3.25$ & $18.605^{\mathrm{b}} \pm 1.55$ \\
\hline
\end{tabular}

${ }^{\mathrm{a}, \mathrm{b}}$ Means with the same superscript letter in the same column are not significantly different $(P>0.05)$.

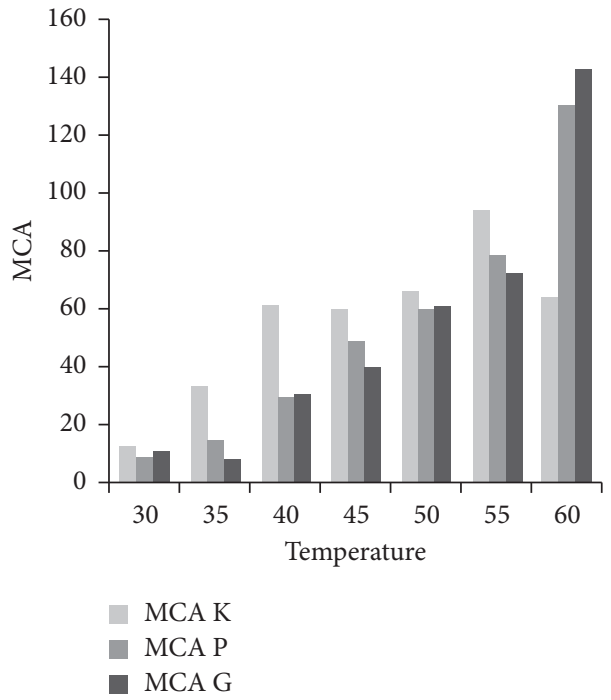

(a)

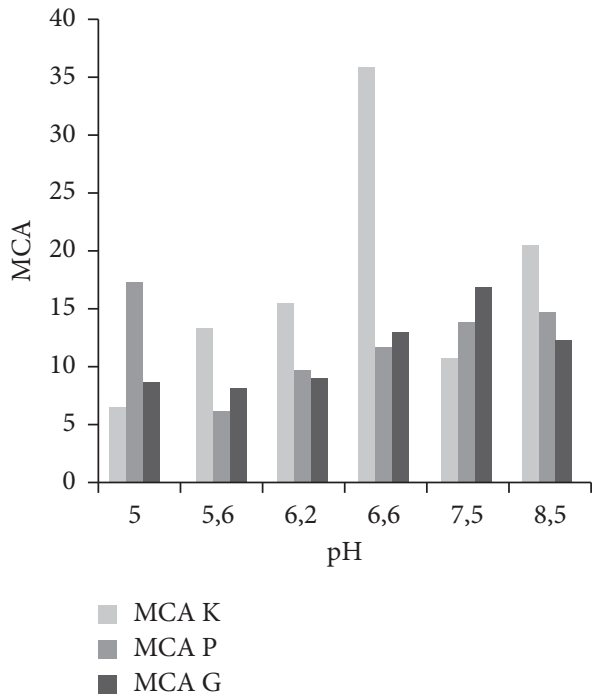

(b)

FIGURE 1: Optimum condition of clotting activity of enzymatic enzyme: (a) optimum temperature; (b) optimum pH. MCA K: milk-clotting activity of kiwi; MCA P: milk-clotting activity of pineapple; MCA G: milk-clotting activity of ginger.

3.3. Proteolytic Activity. The result of proteolytic activity using different enzymatic extracts compared to chymosin is shown in Figure 2.

Figure 2 shows that camel milk with kiwifruit has the lowest proteolytic activity compared to other enzymatic extracts. In the cheese industry, it is still sought that the coagulating enzymes used have high coagulant activity and low proteolytic activity [34].

The proteolytic activity of the extracts depends on several factors, such as the plant source, concentration, and type of protease [35].

3.4. Cheese Curd Yield. Kiwifruit showed the highest curd yield (20.71\%, Figure 3 ) when compared to chymosin and other plant coagulants in camel milk. This result is similar to that of Mazorra-Manzano et al. [21], which mentioned a higher yield using kiwifruit than that of melon and ginger but lowest than chymosin in cow milk. This can be explained by the fact that cheese yield also depends on other factors such as milk quality and composition, heat treatment of milk, type of cheese, and the processing methods used [21].
Plant coagulants have long been considered as possible substitutes for chymosin in the cheese-making process, but their potential for such use depends on their catalytic properties, stability, and specificity, as these factors can affect cheese yield and sensory properties [36]. In the cheese industry, the choice of the coagulating enzyme is a very determining factor. The most appropriate enzyme is the one with the highest clotting activity. The clotting activity is very variable because it is strongly influenced by the state of maturity of the plant and by the conditions of collection and storage [37].

3.5. Physicochemical Characteristics of Curd Cheese. The physicochemical characteristics of camel cheese with different enzymatic extracts (pineapple, kiwifruit, and ginger) are shown in Table 2.

A significant difference on ash and protein content depending on the type of extract was revealed. The curd obtained with ginger extract showed the lowest $(P<0.05)$ water content overall although this is still in the range of $60-70 \%$ reported for fresh cheese $[38,39]$. Proteins content was higher in camel milk cheese with pineapple than kiwi and ginger. 


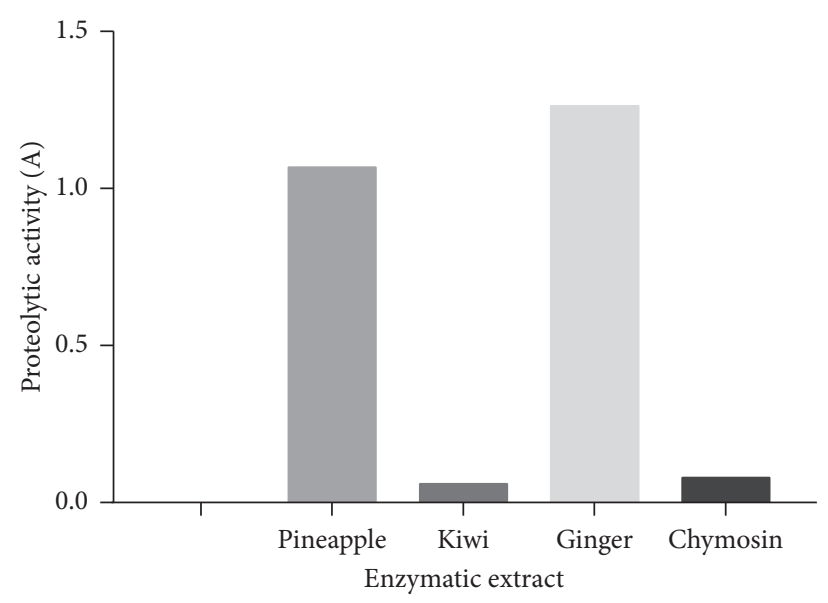

Figure 2: Proteolytic activity of enzymatic extract.

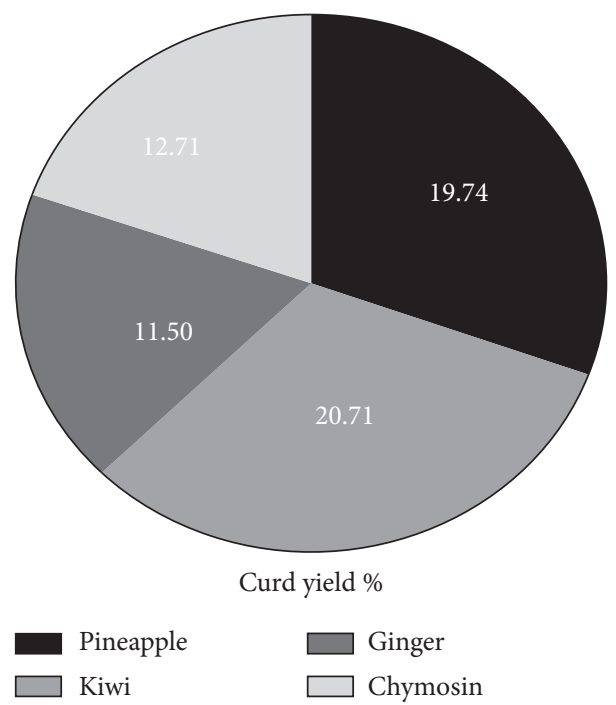

FIgURE 3: Curd yield (\%) with different enzymatic extracts (chymosin, pineapple, kiwi, and ginger).

TABle 2: Physicochemical characteristics of camel's cheese.

\begin{tabular}{lccccc}
\hline Types of cheese & $\mathrm{pH}$ & Dry matter (\%) & Ash (\%) & Humidity (\%) & Proteins (g/L) \\
\hline CMC P & $5.47 \pm 0.03^{\mathrm{a}}$ & $38.16 \pm 4.13^{\mathrm{a}}$ & $9.13 \pm 0.16^{\mathrm{b}}$ & $61.8 \pm 4.13^{\mathrm{a}}$ & $28.42 \pm 0.13^{\mathrm{b}}$ \\
CMC K & $6.01 \pm 0.02^{\mathrm{a}}$ & $35.15 \pm 0.74^{\mathrm{a}}$ & $5.19 \pm 0.32^{\mathrm{a}}$ & $64.85 \pm 0.74^{\mathrm{a}}$ & $31.25 \pm 0.47^{\mathrm{a}}$ \\
CMC G & $6.13 \pm 0.02^{\mathrm{a}}$ & $38.62 \pm 1.52^{\mathrm{a}}$ & $12.02 \pm 0.47^{\mathrm{d}}$ & $61.38 \pm 1.52^{\mathrm{a}}$ & $31.28 \pm 0.30^{\mathrm{a}}$ \\
\hline
\end{tabular}

${ }^{\mathrm{a}, \mathrm{b}}$ Means in the same line followed by the same letter are not statistically different $P>0.05$; CMC P: camel milk cheese with pineapple; CMC K: camel milk cheese with kiwi; CMC G: camel milk cheese with ginger; CMC Chy: camel milk cheese with chymosin.

3.6. Vitamins and Mineral Content of Cheese. The fat-soluble vitamins analyzed were $\mathrm{K}$ and $\mathrm{E}$, and the water-soluble vitamins were B5, B7, and B12. The result is shown in Table 3.

Camel cheese with kiwifruit showed higher levels of water-soluble vitamins B7 $(375,034 \mathrm{mg} / \mathrm{kg}), \mathrm{B} 12$, and B5 compared to camel cheese with other enzymatic extracts (pineapple and ginger). The main fat-soluble vitamins detected in camel cheese was vitamin $\mathrm{E}$.

As shown in Table 4, the most predominant mineral element in camel cheese with different enzymatic extracts was $\mathrm{Na}, \mathrm{K}, \mathrm{Ca}, \mathrm{Mg}, \mathrm{Zn}$, and Fe. Mineral content of camel cheese with kiwifruit was higher than other extracts especially in $\mathrm{Na}(605.2 \mathrm{ppm})$ and $\mathrm{Ca}(63.11 \mathrm{ppm})$ content.

3.7. Texture Profile Analysis (TPA) of Cheese Curds. The results of TPA analysis of fresh cheese curds produced from the different plant coagulants are shown in Table 5 .

Cheese curd texture varied greatly as a function of the different treatments, ranging from 1.15 to $4.33 \mathrm{MJ}$ $(P<0.05)$. The highest values $(P>0.05)$ were obtained for curds made with chymosin and kiwi (4.21 MJ and 4.33 MJ, respectively), while curd made with ginger showed the 
TABLE 3: Fat-soluble and water-soluble vitamins of cheese with different enzymatic extracts.

\begin{tabular}{|c|c|c|c|c|c|c|c|}
\hline Water-soluble vitamins & CMC P & CMC K & CMC G & Fat-soluble vitamins & CMC P & CMC K & CMC G \\
\hline B5 (ppm) & 0.032 & 0.115 & 0.108 & $\mathrm{~K}(\mathrm{ppm})$ & 0.002 & 0.003 & 0.379 \\
\hline B7 (ppm) & 161.263 & 375.034 & 37.784 & - & - & - & - \\
\hline $\mathrm{B} 12(\mathrm{ppm})$ & 1.428 & 3.338 & 1.895 & $\mathrm{E}(\mathrm{ppm})$ & 0.154 & 0.114 & 0.419 \\
\hline
\end{tabular}

CMC P: camel milk cheese with pineapple; CMC K: camel milk cheese with kiwi; CMC G: camel milk cheese with ginger; CMC Chy: camel milk cheese with chymosin.

TABLe 4: Mineral composition of camel cheese with different enzymatic extracts.

\begin{tabular}{lcccccc}
\hline & $\mathrm{Na}(\mathrm{ppm})$ & $\mathrm{K}(\mathrm{ppm})$ & $\mathrm{Ca}(\mathrm{ppm})$ & $\mathrm{Mg}(\mathrm{ppm})$ & $\mathrm{Zn}(\mathrm{ppm})$ & $\mathrm{Fe}(\mathrm{ppm})$ \\
\hline CMC P & 5.7 & 9.43 & 19.97 & 1.3 & 0.25 & 0.099 \\
CMC K & 605.2 & 15.08 & 63.11 & 6.9 & 0.256 & 0.381 \\
CMC G & 9.03 & 17.3 & 61.21 & 1.69 & 0.22 & 0.188 \\
\hline
\end{tabular}

CMC P: camel milk cheese with pineapple; CMC K: camel milk cheese with kiwi; CMC G: camel milk cheese with ginger; CMC Chy: camel milk cheese with chymosin.

TABLE 5: Effect of type of coagulant on curd texture profile analysis (TPA).

\begin{tabular}{lr}
\hline Camel milk cheese & Texture (MJ) \\
\hline CMC P & $2.35 \pm 0.46^{\mathrm{c}}$ \\
CMC K & $4.33 \pm 0.20^{\mathrm{a}}$ \\
CMC G & $1.15 \pm 0.42^{\mathrm{c}}$ \\
CMC Chy & $4.21 \pm 0.32^{\mathrm{a}}$ \\
\hline
\end{tabular}

Values with different superscript letters within the same column are different $(P<0.05)$. Values are the mean \pm standard deviation. CMC P: camel milk cheese with pineapple; CMC K: camel milk cheese with kiwi; CMC G: camel milk cheese with ginger; CMC Chy: camel milk cheese with chymosin.

TABLE 6: Sensory evaluation of camel curd cheese with different extracts.

\begin{tabular}{|c|c|c|c|c|c|}
\hline & Taste & Texture & Odor & Acidity & Color \\
\hline CMC P & $6.26^{\mathrm{a}} \pm 2.69$ & $5.03^{\mathrm{b}} \pm 2.63$ & $6.26^{\mathrm{bc}} \pm 2.52$ & $6.06^{\mathrm{b}} \pm 2.22$ & $5.62^{\mathrm{b}} \pm 2.56$ \\
\hline CMC K & $3.85^{\mathrm{b}} \pm 2.76$ & $6.38^{\mathrm{a}} \pm 2.57$ & $6.38^{\mathrm{b}} \pm 2.01$ & $6.12^{\mathrm{b}} \pm 2.42$ & $5.81^{c} \pm 2.15$ \\
\hline CMC G & $6.18^{\mathrm{a}} \pm 2.43$ & $4.38^{\mathrm{c}} \pm 3.02$ & $6.73^{\mathrm{a}} \pm 2.07$ & $6.62^{a} \pm 2.16$ & $5.57^{\mathcal{C}} \pm 2.56$ \\
\hline CMC Chy & $1.70^{\mathrm{c}} \pm 1.49$ & $4.64^{\mathrm{b}} \pm 2.92$ & $2.54^{\mathrm{b}} \pm 2.11$ & $2.91^{\mathrm{ab}} \pm 2.87$ & $4.38 \pm 3.34$ \\
\hline
\end{tabular}

Values with different superscript letters within the same column are different $(P<0.05)$. Values are the mean \pm standard deviation.

lowest value $(1.15 \mathrm{MJ})$. These results on curd deformation agree with the proteolytic activities of the extracts, which were higher for the ginger extract and lower for the control (chymosin) and kiwi extract (Figure 2). This result was similar to that published by Mazorra-Manzano et al. [21] who found highest curd hardness in kiwi fruits than melon and ginger in cow cheese.

3.8. Sensory Evaluation of Curd Cheese. The sensory quality of cheeses varies according to the manufacturing technology and the chemical and microbiological characteristics of the raw material used. The result of sensory evaluation is shown in Table 6.
Adding enzymatic extract had significant effect on taste, texture, smell, acidity, and color of camel cheese. However, camel cheese with ginger was more acid than other extracts and that with kiwifruit has the best texture. The cheeses obtained are characterized by a slightly bitter taste whatever the extract used. Benani [40] stated that the coagulant agent is characterized by a high proteolytic activity which confers a bitter taste on cheese.

According to the preference test (Figure 4), camel cheese with kiwifruit was preferred by consumer (50\%) compared to cheese with the other enzymatic extracts. This result was in agreement with the physicochemical and rheological characteristic of camel cheese made with kiwifruit as coagulant. 


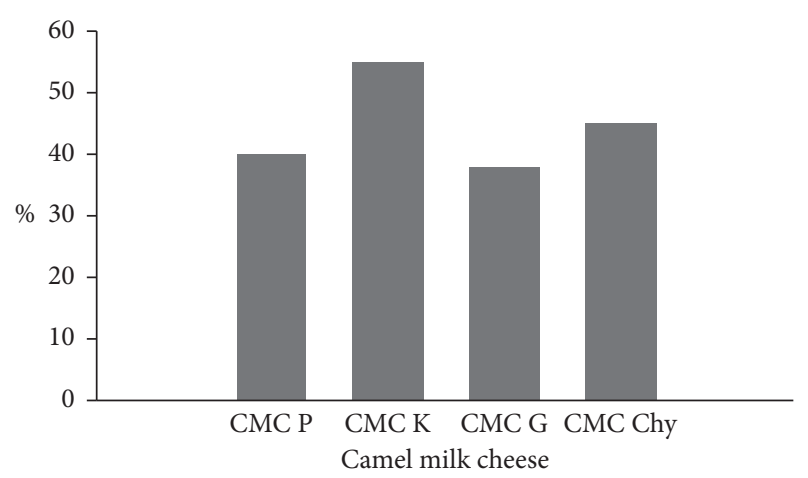

Figure 4: Preference test of camel cheese with different extracts. CMC P: camel milk cheese with pineapple; CMC K: camel milk cheese with kiwi; CMC G: camel milk cheese with ginger; CMC Chy: camel milk cheese with chymosin.

\section{Conclusion}

The kiwi enzymatic extract showed the highest potential for use as a milk-clotting agent in camel milk cheese making since it produced a curd with similar characteristics to those obtained when using commercial chymosin.

The textural properties of fresh curds obtained with kiwi and pineapple extracts were similar to those produced using chymosin. The differences observed between plant coagulants and chymosin may have some effect on the texture and flavor of cheeses, opening the possibility for the production of new cheese varieties with additional plant flavors.

\section{Data Availability}

The datasets generated during and/or analyzed during the current study are available from the corresponding author on reasonable request.

\section{Conflicts of Interest}

The authors declare that there are no conflicts of interest regarding the publication of this paper.

\section{Authors' Contributions}

Imen Fguiri designed and performed the experiments with help of Marzougui Chayma. Imen Fguiri, Moufida Atigui, and Amel Sboui analyzed the data and wrote the manuscript. Samira Arroum and Moahmed Dbara contributed in the experimental analysis. Touhami Khorchani and Mohamed Hammadi revised the paper.

\section{Acknowledgments}

The authors are grateful to central laboratory technicians in Arid Lands Institute for their collaboration in biochemical analysis.

\section{References}

[1] G. Konuspayeva and B. Faye, "Camel milk products in traditional and modern way," in Proceedings of the International
Workshop on Camel Dairy Technologies, Dire Dawa, Ethiopia, July 2016.

[2] Z. Farah, "Composition and characteristics of camel milk; review," Journal of Dairy Research, vol. 60, no. 4, pp. 603-626, 1993.

[3] Z. Farah, Camel Milk Properties, SKAT, Sweden, 1st edition, 1996.

[4] S. R. Kappeler, H. M. van den Brink, H. Rahbek-Nielsen et al., "Characterization of recombinant camel chymosin reveals superior properties for the coagulation of bovine and camel milk," Biochemical and Biophysical Research Communications, vol. 342, no. 2, pp. 647-654, 2006.

[5] Y. Hailu, E. B. Hansen, E. Seifu, M. E. Guya, and R. H. Ipsen, "Factors influencing the gelation and rennetability of camel milk using camel chymosin," International Dairy Journal, vol. 60, pp. 62-69, 2016.

[6] M. Mbye, B. Sobti, K. M. Al Nuami et al., "Physicochemical properties, sensory quality, and coagulation behavior of camel versus bovine milk soft unripened cheeses," NFS Journal, vol. 20, pp. 28-36, 2020.

[7] J. P. Ramet, The Technology of Making Cheese from Camel Milk (Camelus dromedarius), Food Agricuture Organiation, Rome, Italy, 2001.

[8] O. Rolet-Repecaud, F. Berthier, E. Beuvier et al., "Characterization of the non-coagulating enzyme fraction of different milk-clotting preparations," LWT-Food Science and Technology, vol. 50, no. 2, pp. 459-468, 2013.

[9] M. A. Shah, S. Mir, and M. A. Paray, "Plant proteases as milkclotting enzymes in cheesemaking: a review," Dairy Science Technology, vol. 94, no. 1, pp. 5-16, 2014.

[10] B. R. D. C. Leite Júnior, A. A. L. Tribst, N. J. Grant, R. Y. Yada, and M. Cristianini, "Biophysical evaluation of milk-clotting enzymes processed by high pressure," Food Research International, vol. 97, pp. 116-122, 2017.

[11] X. W. Huang, L. J. Chen, Y. B. Luo, H. Y. Guo, and F. Z. Ren, "Purification, characterization, and milk coagulating properties of ginger proteases," Journal of Dairy Science, vol. 94, no. 5, pp. 2259-2269, 2011.

[12] G. I. Katsaros, G. Tavantzis, and P. S. Taoukis, "Production of novel dairy products using actinidin and high pressure as enzyme activity regulator," Innovative Food Science \& Emerging Technologies, vol. 11, no. 1, pp. 47-51, 2010.

[13] A. Ben Amira, S. Besbes, H. Attia, and C. Blecker, "Milkclotting properties of plant rennets and their enzymatic, rheological, and sensory role in cheese making: a review," International Journal of Food Properties, vol. 20, no. 1, pp. S76-S93, 2017.

[14] M. M. Grozdanovic, L. Burazer, and M. Gavrovic-Jankulovic, "Kiwifruit (Actinidia deliciosa) extract shows potential as a low-cost and efficient milk-clotting agent," International Dairy Journal, vol. 32, no. 1, pp. 46-52, 2013.

[15] L. B. Roseiro, M. Barbosa, J. M. Ames, and R. A. Wilbey, "Cheesemaking with vegetable coagulants-the use of Cynara L. for the production of ovine milk cheeses," International Journal of Dairy Technology, vol. 56, no. 2, pp. 76-85, 2003.

[16] P. Verissimo, C. Esteves, C. Faro, and E. Pires, "The vegetable rennet of Cynara cardunculus L. contains two proteinases with chymosin and pepsin-like specificities," Biotechnology Letters, vol. 17, no. 6, pp. 621-626, 1995.

[17] O. C. Aworh and H. G. Muller, "Cheese-making properties of vegetable rennet from sodom apple (Calotropis procera)," Food Chemistry, vol. 26, no. 1, pp. 71-79, 1987.

[18] H.-P. Su, M.-J. Huang, and H.-T. Wang, "Characterization of ginger proteases and their potential as a rennin replacement," 
Journal of the Science of Food and Agriculture, vol. 89, no. 7, pp. 1178-1185, 2009.

[19] L. Feijoo-Siota and T. G. Villa, "Native and biotechnologically engineered plant proteases with industrial applications," Food and Bioprocess Technology, vol. 4, no. 6, pp. 1066-1088, 2011.

[20] M. Ha, A. E.-D. Bekhit, A. Carne, and D. L. Hopkins, "Comparison of the proteolytic activities of new commercially available bacterial and fungal proteases toward meat proteins," Journal of Food Science, vol. 78, no. 2, pp. C170-C177, 2013.

[21] M. A. Mazorra-Manzano, T. C. Perea-Gutiérrez, M. E. LugoSánchez et al., "Comparison of the milk-clotting properties of three plant extracts," Food Chemistry, vol. 141, pp. 1902-1907, 2013.

[22] AFNOR, Contrôle de la Qualité des Produits Alimentaires: Lait et Produits Laitiers : Analyses Physicochimiques, p. 581, 4th edition, AFNOR, Paris, France, 1993.

[23] M. M. Bradford, "A rapid and sensitive method for the quantitation of microgram quantities of protein utilizing the principle of protein-dye binding," Analytical Biochemistry, vol. 72, no. 1-2, pp. 248-254, 1976.

[24] M. Kunitz, "Crystalline soybean trypsin inhibitor," Journal of General Physiology, vol. 30, no. 4, pp. 291-310, 1947.

[25] N. J. Berridge, "488. An improved method of observing the clotting of milk containing rennin," Journal of Dairy Research, vol. 19, no. 3, pp. 328-329, 1952.

[26] J. C. Collin, R. Grappin, and Y. Legraet, "Étude de la méthode de mesure, selon Berridge, du temps de coagulation du lait additionné d'une solution enzymatique," Rev. Lait. Franç.vol. 355, pp. 389-439, 1977.

[27] J. L. Bergere and J. Lenoir, "Les accidents de fromagerie et les défauts des fromages," in Le Fromage, A. Eck and J. C. Gillis, Eds., pp. 509-541, Tec \& Doc Lavoisier, Paris, France, 3rd edition, 1997.

[28] S. Albala-Hurtado, M. T. Veciana-Noguès, M. IzquierdoPulido, and A. Mariné-Font, "Determination of water-soluble vitamins in infant milk by high-performance liquid chromatography," Journal of Chromatography A, vol. 778, pp. 247-253, 1997.

[29] H. S. Boudjenah, "Aptitudes à la transformation du lait de chamelle en produits dérivés: effet des enzymes coagulantes extraites de caillettes de dromadaires," Ph. D. Thesis, Universite Mouloud Mammeri de TiziOuzou (Algérie), Tizi Ouzou, Algeria, 2012.

[30] J. P. Ramet, Production de Fromages à Partir de Lait de Chamelle en Tunisie, pp. 1-33, FAO, Rome, Italy, 1989.

[31] T. T. Truc, L. K. Thanh, and N. V. Muoi, Effect of $p H$ and Temperature on Activity of Bromelain in Pineapple Fruit, Department of Food Technology, Can Tho University, Can Tho, Vietnam, 1999.

[32] A. R. Castillo, J. B. Meehl, G. Morgan, A. Schutz-Geschwender, and M. Winey, "The yeast protein kinase Mpslp is required for assembly of the integral spindle pole body component Spc42p," Journal of Cell Biology, vol. 156, no. 3, pp. 453-465, 2002.

[33] A. J. Barrett, N. D. Rawlings, and J. F. Woessner, Handbook of Proteolytic Enzymes, pp. 843-846, Academic Press, San Diego, CA, USA, 1998.

[34] J. P. Ramet, "Technologie comparée des différents types de caillés," in Le Fromage, A. Eck and J. C. Gillis, Eds., pp. 333-364, Technique \& Documentation-Lavoisier, Paris, France, 1997.

[35] M. P. C. Silvestre, R. L. Carreira, M. R. Silva, F. C. Corgosinho, M. R. P. Monteiro, and H. A. Morais, "Effect of $\mathrm{pH}$ and temperature on the activity of enzymatic extracts from pineapple peel," Food and Bioprocess Technology, vol. 5, no. 5, pp. 1824-1831, 2012.

[36] M. Jacob, D. Jaros, and H. Rohm, "Recent advances in milk clotting enzymes," International Journal of Dairy Technology, vol. 64, no. 1, pp. 14-33, 2011.

[37] R. Veisseyre, Technologie du Lait: Constitution, Récolte, Traitement et Transformation du Lait, pp. 9-33, La Maison Rustique, Paris, France, 1979.

[38] C. Lobato-Calleros, L. Ramos-Solis, A. Santos-Moreno, and M. Rodriguez-Huezo, "Microstructure and texture of panela type cheese-like products: use of low methoxyl pectin and canola oil as milk-fat substitutes," Revista Mexicana de Ingenieria Qúimica, vol. 5, pp. 71-79, 2006.

[39] M. J. Torres-Llanez, B. Vallejo-Cordoba, M. E. Díaz-Cinco, M. A. Mazorra-Manzano, and A. F. González-Córdova, "Characterization of the natural microflora of artisanal Mexican Fresco cheese," Food Control, vol. 17, no. 9, pp. 683-690, 2006.

[40] S. T. Benani, "Valorisation et optimisation de l'utilisation d'un coagulant végétal pour la fabrication d'un fromage traditionnel: composition and characteristics of camel milk," Journal of Dairy Research, vol. 60, no. 1993, pp. 603-626, 2017. 